\title{
SUITABLE MEASURES AGAINST THE POLLUTION OF THE RHINE BY CHLORIDE DISCHARGE FROM THE ALSATIAN POTASH MINES
}

\author{
L. J. HUIZENGA
}

International Commission for Protection of the Rhine against Pollution, 54 Koblenz, Postfach 309, W. Germany

\begin{abstract}
A great number of organic and inorganic substances pollute the water of the Rhine. The greatest concentration is formed by the chlorides, as their quantity exceeds that of the sulphates by about 50 per cent. At the German-Dutch frontier, the mean annual value of the chloride charge of the river amounts to approximately $350 \mathrm{~kg} / \mathrm{s} \mathrm{Cl}^{-}$. About 40 per cent, or $130 \mathrm{~kg} / \mathrm{s}$, of this quantity are residual salts originating from the French potash mines in Alsace. As the chloride charge of the Rhine causes considerable damage to Dutch horticulture and the public supply of both drinking water and industrial water, a solution for the problem of the salt discharges in Alsace is sought within the framework of the International Commission for the Protection of the Rhine from Pollution. By means of a separation process, $\mathrm{KCl}$ is extracted from the sylvinite hauled from the mines (58 per cent $\mathrm{NaCl}, 28$ per cent $\mathrm{KCl}$ and 14 per cent marl), while the residual salt, about 7 million tons per year, is drained off into the Rhine.

Non-realizable solutions for effecting a reduction of this discharge are:

(1) Measures within the production process

(2) Filling of the residual salt into the hollow spaces left by mining

(3) Sale of the residual salt to soda works

(4) Discharge, through a pipeline, into the sea

One possible solution would be deposition in a dumping area, but this might endanger the rich ground-water resources of Alsace. At present, a two-year hydrological investigation at a $20 \mathrm{~m}$ high trial pile is being complemented by studies on suitable sealing, piling and transporting techniques at different locations.

The possibility of transportation by ship has also been taken into consideration. For this purpose, another investigation is actually being carried out.
\end{abstract}

\section{INTRODUCTION}

By means of chemical investigations of the Rhine water, the presence of a great number of organic and inorganic substances can be ascertained. Results of such an investigation indicate that in the lower Rhine section a chloride concentration prevails, exceeding the subsequent sulphate concentration by about 50 per cent.

Figure $I$ represents the chloride charge for the sampling station at the 


\section{J. HUIZENGA}

German-Dutch frontier by giving an historical review, which distinctly sets off the crisis in the thirties, the end of World War II and the great industrial development after 1945 in the countries bordering the Rhine.

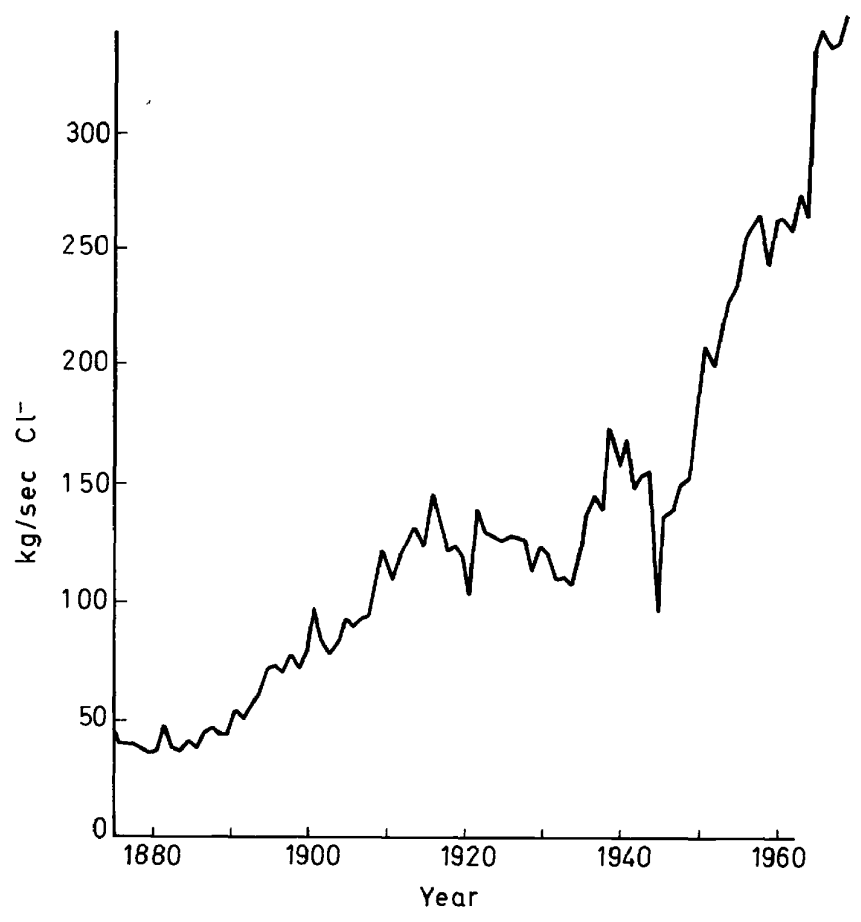

Figure 1. Chloride load of the Rhine.

At the German-Dutch frontier the chloride charge is composed as follows:

(1) Residual salts from the French potash mines in Alsace

(2) Soda works

(3) Remaining industries

(4) Natural salt charge

(5) Pit water from the mineral coal industry in the 'Ruhr-district'

(6) Potash mines of Buggingen (BadenWürttemberg)

(7) Share of population (households)

$130 \mathrm{~kg} / \mathrm{s} \mathrm{Cl}^{-} \quad 37 \%$

$70 \mathrm{~kg} / \mathrm{s} \mathrm{Cl}^{-} \quad 20 \%$

$50 \mathrm{~kg} / \mathrm{s} \mathrm{Cl}^{-} \quad 14 \%$ $45 \mathrm{~kg} / \mathrm{s} \mathrm{Cl}^{-} \quad 13 \%$

$40 \mathrm{~kg} / \mathrm{s} \mathrm{Cl}^{-} \quad 11 \%$

$10 \mathrm{~kg} / \mathrm{s} \mathrm{Cl}^{-} \quad 3 \%$

\begin{tabular}{rr}
$5 \mathrm{~kg} / \mathrm{s} \mathrm{Cl}^{-}$ & $2 \%$ \\
\hline $350 \mathrm{~kg} / \mathrm{s} \mathrm{Cl}^{-}$ & $100 \%$
\end{tabular}

The mean discharge of the Rhine amounts to $2250 \mathrm{~m}^{3} / \mathrm{s}$, and the mean chloride concentration consequently to $155 \mathrm{mg} / \mathrm{l}$. As the chloride load does not depend upon water flow except for the natural part, a chloride concentration of more than $300 \mathrm{mg} / \mathrm{l} \mathrm{can}$ in fact occur in dry times, and concentrations of more than $400 \mathrm{mg} / \mathrm{l}$ in times of very low flow. 


\section{WATER POLLUTION IN SALT AND POTASH MINING}

In consequence of the chloride contents of the Rhine water, considerable damage to the following sectors is caused in the Netherlands:

(1) The public supply of drinking water concerning deterioration of taste, especially owing to the formation of chlorophenols. The standard of the World Health Organization for the chloride contents of drinking water comes to 200 $\mathrm{mg} / \mathrm{l}$; in dry times it is however often exceeded.

(2) The industries, which use demineralized water for high-pressure boilers and for production.

(3) The highly developed horticulture in the Westland and the flower cultivation in the region of Aalsmeer, through loss of profit.

The Netherlands wish a reduction of the chloride concentration to $200 \mathrm{mg} / \mathrm{l}$, and if possible even to $150 \mathrm{mg} / \mathrm{l}$. Besides this the chloride charge should be decreased to not more than $225 \mathrm{~kg} / \mathrm{s}$.

For several years the International Commission for the Protection of the Rhine against Pollution, whose members are Switzerland, France, Federal Republic of Germany, Luxembourg and the Netherlands, has been trying to find a solution for this problem, in order to decrease the above-mentioned damage to an acceptable level.

First of all it has tried to reduce the discharge of the French potash mines in Alsace. Since these mines discharge the greatest part, the most efficient steps could be taken right here. The solid structure of the residual salt represents another favourable factor in the solution of this problem.

\section{THE PRODUCTION PROCESS OF THE ALSATIAN POTASH PLANTS}

In the National Alsatian potash mines (see Figure 2) sylvinite, a compound of 28 per cent $\mathrm{KCl}, 58$ per cent $\mathrm{NaCl}$ and 14 per cent marl is mined about $700 \mathrm{~m}$ under the ground surface. The potash plants near the mines make use of two processes to separate the $\mathrm{KCl}$ and the $\mathrm{NaCl}$ : the dissolution process (about 60 per cent of the production) and the flotation process.

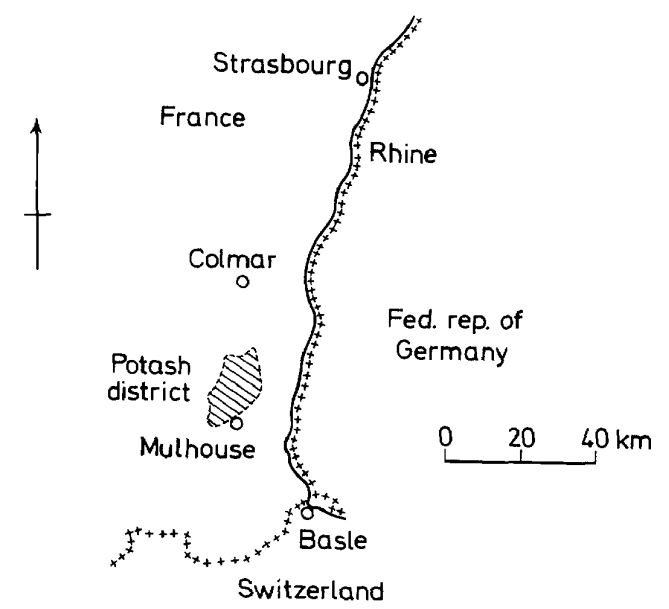

Figure 2. Map of the potash district. 


\section{(a) The dissolution process}

This is based on the physical phenomenon, that the solubility of $\mathrm{KCl}$ increases at higher temperatures, while it varies barely in the case of $\mathrm{NaCl}$ (see Figure 3). The first phase of the process is represented by grinding the sylvinite

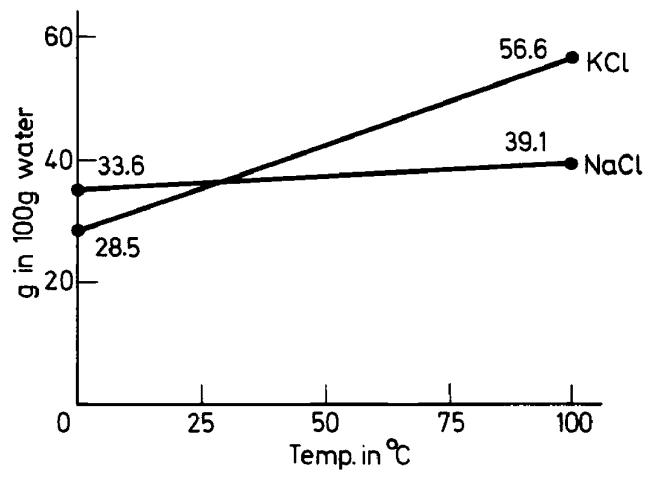

Figure 3. Solubility of $\mathrm{NaCl}$ and $\mathrm{KCl}$.

(see Figure 4). The salt is introduced into a solution boiler containing a mother salt solution of a temperature of approximately $100^{\circ} \mathrm{C}$, which before heating had been saturated with $\mathrm{KCl}$ as well as with $\mathrm{NaCl}$. Under permanent agitating, the $\mathrm{KCl}$ of the admitted salt arrives at a solution, while the $\mathrm{NaCl}$ remains in unsolved condition. The NaCl-grains are removed from the boiler. The $\mathrm{KCl}$ soltuion, which still contains mud, is clarified in settling tanks after addition of a flocking agent. The removed mud is deposited on a special tip. The clarified, still warm $\mathrm{KCl}$-solution is conducted through a number of series-connected crystallization boilers; by means of intensified vaporization the liquid cools down to approximately $25^{\circ} \mathrm{C}$. The thermal energy of the exhausted steam is used in heat exchangers in order to heat the mother salt solution, which remained over at the end of the circuit. The $\mathrm{KCl}$-grains are removed by filtration or deposition, and dried in large rotary furnaces (similar to a rotary cement kiln). The remaining liquid enters the circuit and is pumped into a storage tank containing mother salt solution. While the liquid is pumped from this tank to the solution boiler, it is heated in the heat exchangers to $75^{\circ} \mathrm{C}$ and afterwards with steam to $110^{\circ} \mathrm{C}$. The $\mathrm{KCl}$ coming from the drying stoves has a degree of purity of 95-96 per cent, 4-5 per cent are $\mathrm{NaCl}$.

\section{(b) The flotation process}

This is carried out as follows. After addition of gathering oil and foaming oil, air is introduced, under agitation, into a solution saturated with $\mathrm{KCl}$ and $\mathrm{NaCl}$ and containing very fine, ground sylvinite. The gathering oil has an affinity to $\mathrm{KCl}$, however, not to $\mathrm{NaCl}$. It covers the $\mathrm{KCl}$-grains and makes them ascend to the surface, where they can be removed with the foam. The $\mathrm{NaCl}$ is removed after settling. 
WATER POLLUTION IN SALT AND POTASH MINING

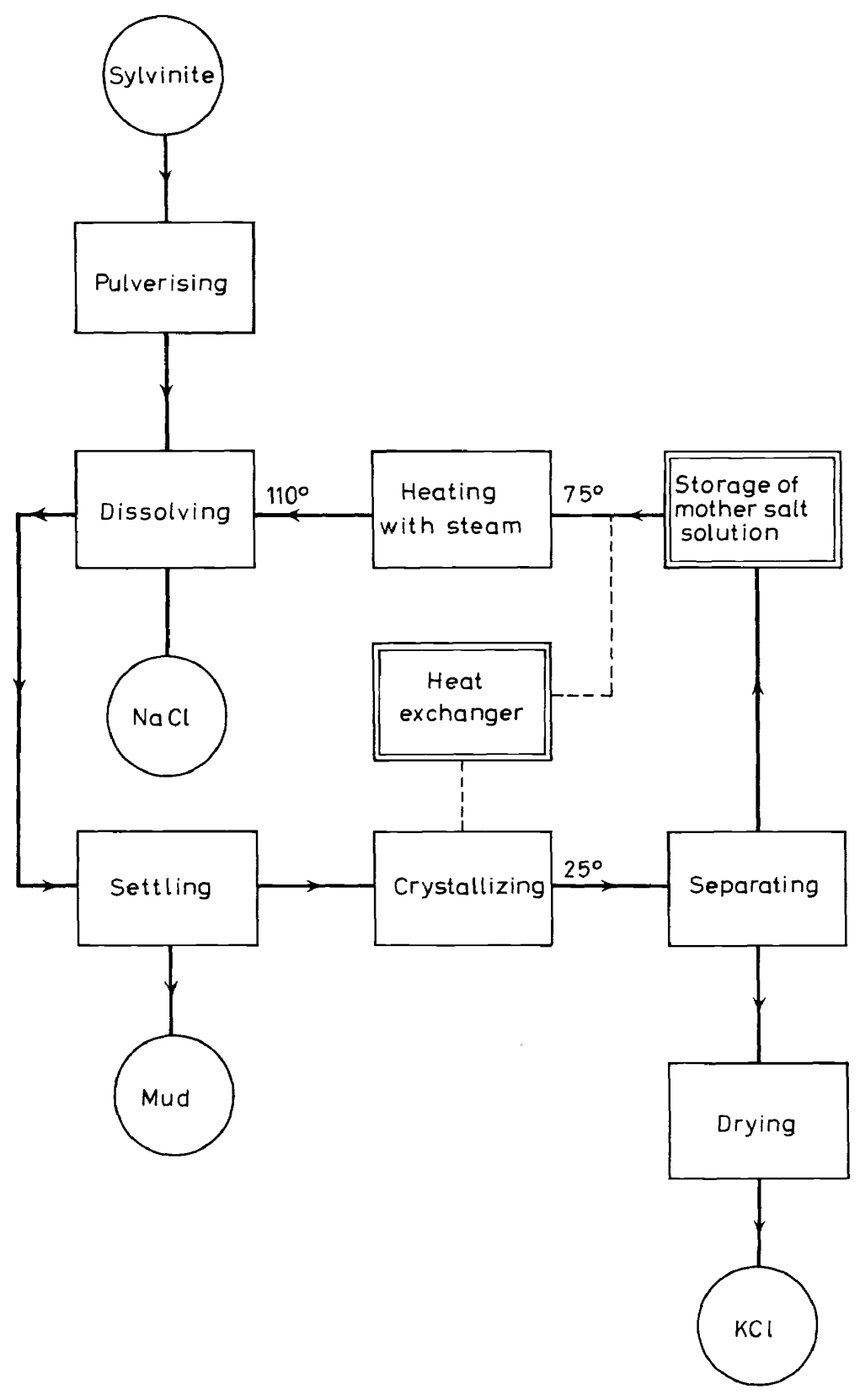

Figure 4. Potash production process. 


\section{J. HUIZENGA}

\section{ACTUAL REMOVAL OF RESIDUAL SALT}

During potash production the residual salt is obtained in solid, grain-like condition, and is composed of 84 per cent $\mathrm{NaCl}, 2.5$ per cent $\mathrm{KCl}, 11.5$ per cent insoluble matter, and 2 per cent water. Should any demand for this product exist, it would have to be classified as a byproduct. As this, however, is not the case, it must be considered as waste.

In the thirties the first dissolved residual salts were drained off into the Rhine. In the course of many years, the volume of these discharges increased to the same extent as the haulage of sylvinite (see Figure 5). The quantity actually

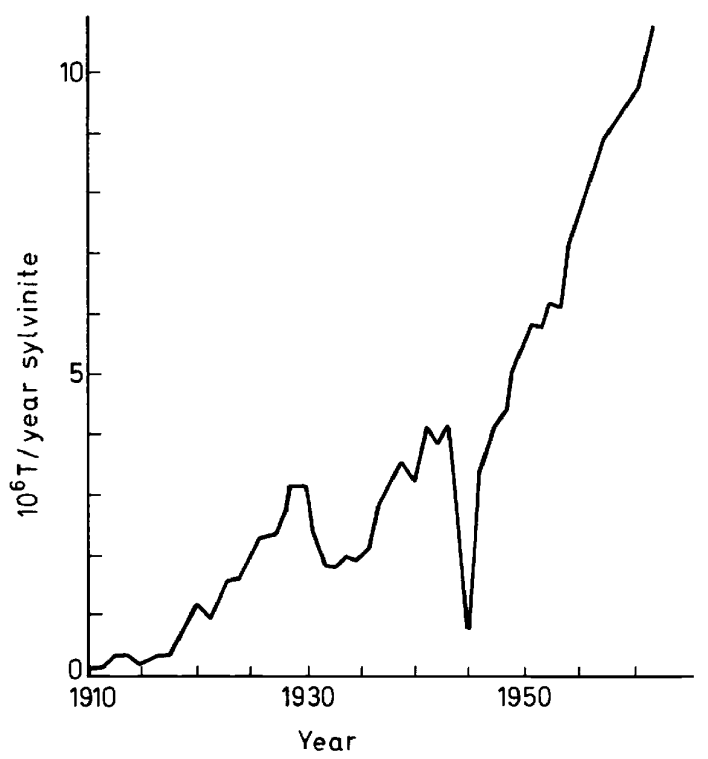

Figure 5. Production of the potash mines.

being discharged into the Rhine amounts to $130 \mathrm{~kg} / \mathrm{s} \mathrm{Cl}^{-}, 11000 \mathrm{t} / \mathrm{day}^{-} \mathrm{Cl}^{-}$, $20000 \mathrm{t} /$ day salt or $7.5 \mathrm{million} \mathrm{t} /$ year salt. In order to avoid too high an increase of the chloride concentration at periods of lower discharges, basins are situated along the Rhine, in which the brine can be stored. From there it is discharged into the Rhine, if the discharge of the river permits doing so. This process corresponds to the conditions required by the decree of the Prefect of Strasbourg.

\section{POSSIBLE MEASURES FOR EFFECTING A REDUCTION OF THE SALT DISCHARGES INTO THE RHINE}

(a) Measures within the production process

From the description of the production process, it can be concluded without further commentary, that measures within the production process are nonrealizable. 


\section{WATER POLLUTION IN SALT AND POTASH MINING}

\section{(b) Sale of the residual salt as de-icing means}

Only a restricted quantity of the residual salt is sold as de-icing means. Especially because of the loamy contents in the salt, the market possibilities can scarcely be improved.

\section{(c) Filling of the residual salt into the hollow spaces left by mining}

For two reasons this possibility must be rejected:

(1) The additional expenditure for transportation in the tunnels and shafts in opposite direction to the already existing sylvinite transport, would cause a considerable increase to the prime cost. The hauling method would also have to be rearranged. Considering the severe competition on the potash market-50 per cent of the French potash output is exported - this possibility can not be realized.

(2) It offers less security for the staff. In the Alsatian potash district, socalled rock bursts may occur, which evoke explosion-like displacements of the rocks under escape of fire damp. By means of special hauling technique 'chambers and pillars' the danger of rock bursts is essentially decreased.

\section{(d) Delivery of residual salts as raw material for soda works}

The possibility of a delivery of residual salts to soda works has also been examined. The soda works of Dombasle near Nancy are ready to treat 1.7 million tons $\mathrm{NaCl}$ per year. For this purpose the salt would have to be delivered as saturated brine in clarified condition through a $160 \mathrm{~km}$ long pipeline. The necessary investment in this case would amount to 80 million $\mathrm{FF}$, and the price for $1 \mathrm{t}$ salt forwarded to Nancy would be $5.80 \mathrm{FF}$ for a duration of 20 years. Up to now the soda works mentioned have taken the salt in dissolved condition from their own deposits. As this is an economic process, a sales price of not more than $0.5 \mathrm{FF} / \mathrm{t}$ could be attained for the residual salt, while the ten-fold costs, as mentioned, would have to be paid for the supply. There is an additional technical difficulty. On its way through the Vosges Mountains, the pipeline would have to surmount rather considerable differences in altitude, whereby pressures of about 50 atm.g would be produced within the pipeline. A corrosion-proof material for pipelines, which is resistant to high pressures has not, up to now, been developed.

Also, particularly because of the unstable market situation for potash and soda, which is incompatible with a long-term delivery contract, the Commission has decided to abandon this intention for the time being.

\section{(e) Pipeline to the sea}

This possibility can only be considered as a theoretical one. In comparison to a pipeline of $160 \mathrm{~km}$ to Nancy, the investment in a pipeline of about $650 \mathrm{~km}$ crossing France or a pipeline of $850 \mathrm{~km}$ along the Rhine would involve multiple costs. The necessary investment and the costs of transportation would increase accordingly.

\section{(f) Tipping in a dumping area}

In the case of entire depositing in a dumping area, a tip of $150 \mathrm{~m}$ height and $400 \mathrm{~m}$ width will result, which will grow larger by $200 \mathrm{~m}$ corresponding to approximately 7 million tons residual salt per year. 


\section{J. HUIZENGA}

It is obvious that the realization of such a project and even that of a partial dumping must be based on exhaustive preliminary investigations. For this reason a trial tip, approximately $20 \mathrm{~m}$ high, was formed on a space of $50 \times 50 \mathrm{~m}$ in 1966, where scientific observations lasting more than 2 years were carried out.

Three different aspects were studied:

(i) the hydrological attitude of a tip, which is subject to atmospheric influences;

(ii) the stability of such a tip;

(iii) the consequences resulting from the foregoing points for the ground water situated beneath.

The total expenses for the investigation amounted to more than 1 million FF and have been met jointly by the countries bordering the Rhine. The results have been noted down in a very comprehensive expert's report and can be summarized as follows:

(i) a dumping area in Alsace may be instituted in principle.

(ii) the base of the tip must be provided with a secure sealing and a network of collecting pipes to drain off the emerging salt water.

(iii) considering the considerable importance of the ground water resources in Alsace, which are gained easily and belong to one of most important presuppositions for the economic development of this region, the tip should be placed at a maximum distance from inhabited areas and zones which are exploited by agriculture.

The investigations on the trial tip are actually complemented by studies on suitable sealing, tipping, and transporting techniques at different locations.

The expenses of 120000 FF for these studies are also jointly met by the countries bordering the Rhine.

\section{(g) Transportation by ship to the North Sea}

The transportation of salt by ship to the North Sea is another possibility. This kind of transportation can be divided into three parts.

(i) Transportation from the mines to the Rhine.

(ii) Transportation by ship to the coast itself.

(iii Conveyance into the North Sea.

The transportation from the mines to the loading wharf on the Rhine is actually being investigated. Therefore, it is still impossible to give any statement about the most economic solution.

The capacity of the existing Rhine fleet does not meet the demand for the transport of 7.5 million tons of salt per year. Therefore, a new fleet would have to be built, comprising approximately 20 push tows and 100 barges. In this case the necessary investment comes to about 150 million DM. The costs of transportation amount to approximately $8 \mathrm{DM}$ per ton, included all risks and the investment.

Moreover also the costs for transport to the loading wharf and the costs for discharge into the North Sea must be added. In course of the last mentioned process it seems to be the most favourable solution to pump the salt hydraulically from the barges to a storage basin and from there through a pipeline into the sea.

Because of economic reasons this project also doubtlessly involves a long- 
term contract. At low water stages the transport capacity can only be exploited partially and in very dry periods suspension of navigation must be expected. In order to avoid a discharge of residual salt into the Rhine during these periods, it would be necessary to have a buffer tip. The Commission continues its deliberation on this intent.

\section{FUTURE OUTLOOK}

In view of the foregoing there should be no doubt that the diversity of aspects aggravates the search for a solution to the problem of salt discharges from the Alsatian potash mines. Tipping in a dumping area would be the simplest and cheapest method. Owing to the danger to the ground water and because of aesthetic reasons the Alsatian population would doubtlessly reject this solution. The possibility of transportation by inland waterway to the North Sea, which would not evoke any objection from the population, can only be realized with enormous expenditures. Also a partial solution, for example 50 per cent dumping tip, 50 per cent discharge, or transport by ship, can still be taken into consideration.

Besides the technical points of view, financial aspects also play an important role within the Commission. A ratio of distribution for the deriving costs has not yet been found. Furthermore, as the studies have not yet been complemented and the realization of such a project takes up very much time, it must be feared that still a lot of water will flow down the Rhine, before a solution concerning the salt discharges from the Alsatian potash mines, acceptable for all countries bordering the Rhine, has been found. 